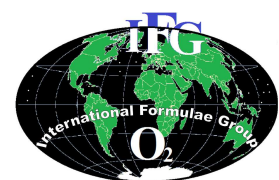

\title{
Characterization of traditional maize populations cultivated in Benin
}

\author{
Justin ABADASSI
}

Faculté des Sciences Agronomiques, Université d'Abomey-Calavi, 03 BP 2547 Cotonou, Bénin. E-mail: jabadassi@gmail.com

\begin{abstract}
Traditional maize populations widely grown in southern Benin were evaluated in that zone for agronomic traits in order to improve them if necessary. A randomized complete block design with four repetitions was used. Significant differences among populations were observed for earliness, plant and ear heights, number of ears per plant and number of grains per ear. One population (PTMB4) was susceptible to rust. All populations except one (PTMB8) showed good husk cover. The populations gave relatively low grain yields (less than $4 \mathrm{t} / \mathrm{ha}$ ) and were not significantly different for that trait. All the populations should be improved for grain yield. In addition, the populations PTMB4 and PTMB8 must be improved respectively for rust resistance and husk cover.
\end{abstract}

(C) 2014 International Formulae Group. All rights reserved.

Keywords: Agronomic traits, southern Benin, traditional varieties, Zea mays.

\section{INTRODUCTION}

Maize is a worldwide cereal crop. It is utilized as human food, animal feed and raw material for several industrial products. Maize world production was about 875 million tons in 2012 (FAO, 2013). The demand is continuously increasing and cannot be satisfied without strong technological interventions (Shiferaw et al., 2011). In Benin, maize is the most cultivated cereal crop and its production was estimated in 2012 at 1175000 tons (FAO, 2013) of which more than half was obtained in the south (ONASA, 2013). Technical, biological, socio-economic and climatic constraints limit maize production in Benin (Adegbola, 1994; Fiagan, 1994; Abadassi, 1997).
Two types of varieties are cultivated in Benin: traditional populations and improved varieties. The traditional populations are the most grown varieties despite important efforts made to popularize improved varieties. They may proceed from natural mating between maize introduced from the Americas via Europe (Westengen et al., 2012; Mir et al., 2013).

Beninese producers and consumers prefer those populations because notably of their adaptation to low-input farming systems, their relatively low susceptibility to storage pests and the good quality of their grains. But, grain yields obtained in farmers' fields are low (less than $1.5 \mathrm{t} / \mathrm{ha}$ ) (FAO, 2013). It is, therefore, important to characterize the populations cultivated in order to improve them if necessary. 
The present work was undertaken to determine the main agronomic traits of traditional maize populations widely grown in southern Benin with the aim of improving them in case of need.

\section{MATERIALS AND METHODS}

\section{Populations and evaluation}

Nine traditional maize populations (Table 1) widely cultivated in southern Benin (Departments of Ouémé, Plateau, Atlantique, Mono, Couffo and Zou) were characterized. They are all usually cultivated during the great rainy season (March to July). An improved maize population created by the International Institute of Tropical Agriculture (IITA) and popularized in Benin, DMRESRW, was used as check. The 10 populations were evaluated during the great rainy season in South Benin at Abomey-Calavi (latitude: 6 ${ }^{\circ} 27^{\prime} \mathrm{N}$; longitude: $2^{\circ} 22^{\prime} \mathrm{E}$; altitude: $10 \mathrm{~m}$ ) in a randomized complete block design with 4 replications. Plots consisted of four $4.5 \mathrm{~m}$ rows. Spacing was $0.80 \mathrm{~m}$ between rows and $0.50 \mathrm{~m}$ between hills along each row. Plots were overplanted and thinned to 2 plants per hill (50000 plants.ha ${ }^{-1}$ ). Applied fertilization was $200 \mathrm{~kg} / \mathrm{ha}$ of NPKSB (14-23-14-5-1) before planting followed by $25 \mathrm{~kg} / \mathrm{ha}$ of urea $(46 \% \mathrm{~N})$ two and six weeks after planting. Weeding was adequate. Rainfall was sufficient and well distributed.

The traits studied were: earliness (days to $50 \%$ pollen-shed, silking and maturity (dried husks) (days after planting), number of leaves), plant height (distance between soil level and panicle base), ear height (distance between soil level and the higher ear insertion point), reaction to diseases (rust caused by Puccinia polysora, tropical blight caused by Exserohilum maydis, and maize streak caused by maize streak virus), husk cover and grain yield and its components.

Diseases were scored after silking, under natural infection, using a 1 - 5 scale $(1=$ very mild infection; 5 = very high infection). Husk cover was scored at maturity with a 1 to 5 scale [ $(1=$ excellent (tight husk going beyond the ear tip); 5 = very poor (naked ear tip)]. For individual plant observations (number of leaves, plant and ear heights, disease score, husk cover), ten plants were randomly taken per plot. Grain yield and 1000 grain weight were recorded on a plot basis at $15 \%$ moisture. Number of ears per plant (nep) and number of grains per ear (nge) were calculated as follows:

nep $=$ ne/nph

with ne $=$ number of ears harvested on the plot;

$\mathrm{nph}=$ number of plants harvested on the plot

nge $=($ gwe/tgw $) \times 1000$

gwe $=$ grain weight per ear

$\operatorname{tg} \mathrm{w}=1000$ grain weight .

Table 1: Few grain characteristics of the traditional populations studied.

\begin{tabular}{lcccc}
\hline Population & Local name & Grain colour & Grain texture & Grain size \\
\hline PTMB1 & Yallode & White & Dent & Small \\
PTMB2 & Agliki & White & Dent & Small \\
PTMB3 & HOLLIKOUI & White & Dent & Small \\
PTMB4 & AZANGBANGBE & White & Dent & Small \\
PTMB5 & TCHAOUNKPO & White-yellow & Dent & Small \\
PTMB6 & GANNANKOUN & White & Dent & Small \\
PTMB7 & GBADEGA & White & Dent & Small \\
PTMB8 & SOUNHATON & White & Dent & Small \\
PTMB9 & GBADEWEWE & White & Dent & Small \\
\hline
\end{tabular}




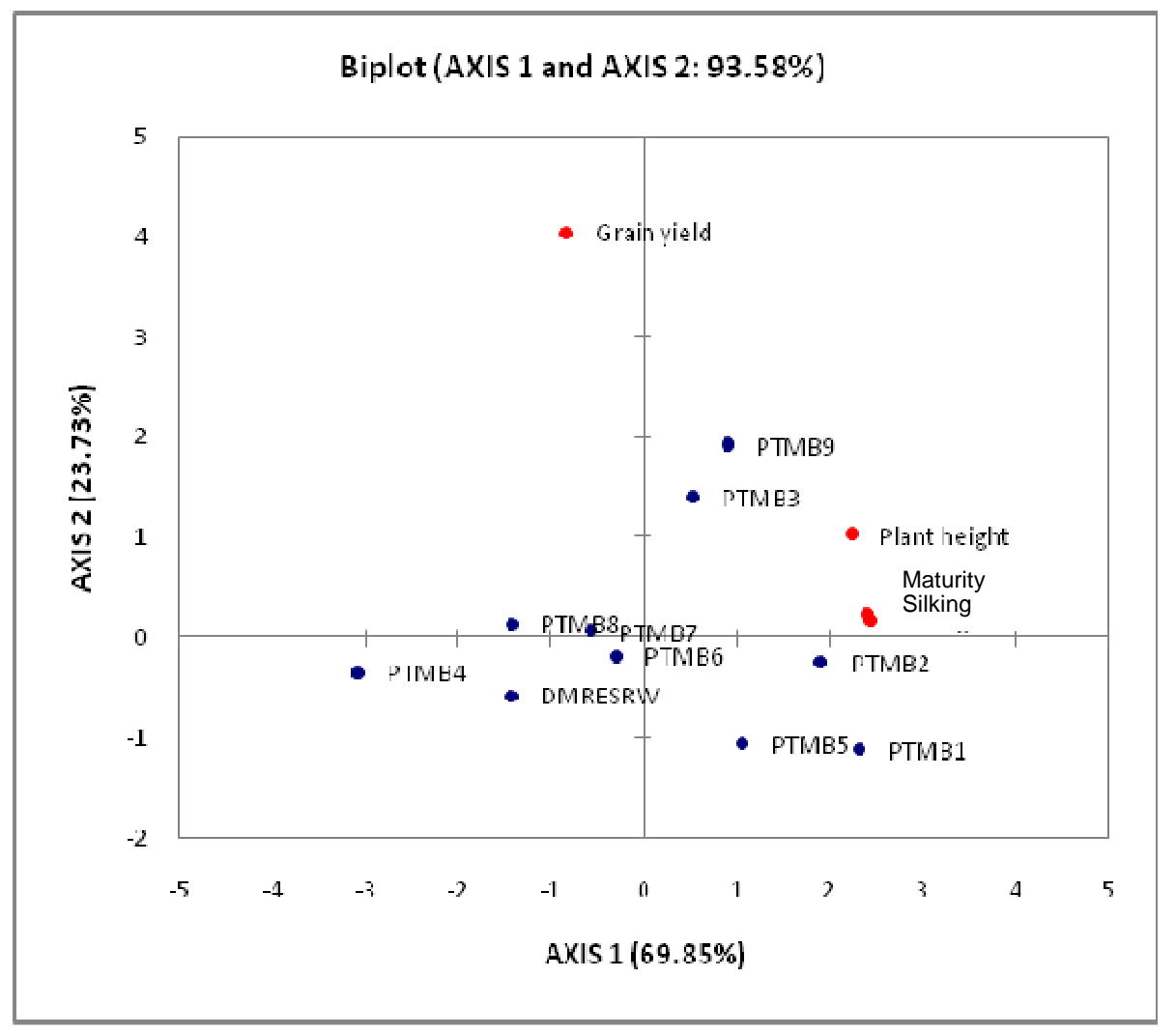

Figure 1: Principal components analysis: Biplot showing the representation of variables and populations in the main plan AXIS 1 AXIS 2. Silking = Days to $50 \%$ silking; Maturity = Days to $50 \%$ maturity.

\section{Statistical analysis}

Analysis of variance was carried out per trait. When significant $(\mathrm{P}<0.05)$ differences among populations appeared, population means were compared using Newman-Keuls test.

Principal components analysis was performed for four key agronomic traits (days to $50 \%$ silking, days to $50 \%$ maturity, plant height and grain yield) to study correlations between traits and examine the relative situations of the populations. The variables were given the same weight.

\section{RESULTS}

Single variable study

Analyses of variance showed significant differences among populations for all traits except 1000 grain weight and grain yield. Population means are given by Tables 2 and 3. Days to $50 \%$ pollen-shed, silking and maturity ranged from 48 to 59,49 to 62 and 80 to 92 respectively. The number of leaves varied from 18 to 22 . Considering flowering and maturity, the improved population DMRESRW appeared later than one traditional population (PTMB4), earlier than 4 traditional populations (PTMB1, PTMB2, PTMB5 and PTMB9) and not significantly different from 3 traditional populations (PTMB6, PTMB7 and PTMB8). PTMB3 was later than DMRESRW for flowering and not significantly different from it for maturity. Significant differences between DMRESRW 
and traditional populations ranged from 3 to 7 days.

Plant and ear heights of the traditional populations varied from 159 to $240 \mathrm{~cm}$ and 66 to $137 \mathrm{~cm}$ respectively. Seven populations (PTMB1, PTMB2, PTMB3, PTMB5, PTMB6, PTMB7 and PTMB9) had plant and ear heights significantly higher than those of DMRESRW $(+46$ to $+79 \mathrm{~cm}$ for plant height and +27 to $+58 \mathrm{~cm}$ for ear height) whereas 2 (PTMB4 and PTMB8) were not significantly different from it.

Except PTMB4 which was susceptible to rust, all the populations showed very mild infection (score 1). Apart from PTMB8, all the traditional populations had a good husk cover. PTMB8 showed, like DMRESRW, an intermediate husk cover.

Number of ears per plant in the traditional populations was between 0.80 and 1.23 whereas the number of grains per ear varied from 235 to 336. Except PTMB4, the traditional populations were not significantly different from the improved population DMRESRW for the number of ears per plant. PTMB4 had a number of ears per plant higher than that of DMRESRW. Two populations (PTMB4 and PTMB7) had numbers of grains per ear significantly lower than that of the check DMRESRW; the other populations were not significantly different from the check for that trait. One thousand grain weight varied from 219 to $254 \mathrm{~g}$ but the differences noted among populations were not significant. Seven of the 9 traditional populations were not then significantly different from the improved population DMRESRW for the 3 grain yield components evaluated.

The traditional populations gave relatively low grain yields ranging from 2.6 to $3.8 \mathrm{t} / \mathrm{ha}$. No significant difference was observed among populations.
Multivariable study: principal components analysis

Table 4 gives the proportion of the total variability explained by the axes. It appears that the first two axes (AXIS 1 and AXIS 2) explain respectively $69.85 \%$ and $23.73 \%$ of the total variability. The plan defined by the two axes explains, therefore, $93.58 \%$ of the total variability and was retained for the representation of variables and populations.

The squared cosines of the variables are shown in Table 5. Table 6 gives the matrix of simple linear correlations of the variables.

The earliness variables (days to $50 \%$ silking, days to $50 \%$ maturity) and plant height are well linked with AXIS 1 whereas grain yield is well linked with AXIS 2.

Days to $50 \%$ silking, days to $50 \%$ maturity and plant height were highly (significance at the 1\% level) and positively correlated but were not significantly correlated with grain yield.

Figure 1 summarizes the relative situations of the populations for the traits studied. Four groups of relatively close populations appear:

Group 1: PTMB3 and PTMB9.

The two populations were relatively late, showed great plant heights and gave relatively low grain yields (less than 4 t/ha).

- Group 2: PTMB1, PTMB2 and PTMB5

The characteristics of this group are: relative lateness, great plant height and relatively low grain yield

- Group 3: PTMB6 and PTMB7.

The two populations of the group were relatively early, had relatively great plant heights and relatively low grain yields

- Group 4: PTMB8 and DMRESRW

Earliness, low plant height and relatively low grain yield characterize that group.

PTMB4 appears relatively isolated. It was the earliest population and had the lowest plant height and a relatively low grain yield. 
Table 2: Population means and their standard errors for earliness variables and plant and ear heights.

\begin{tabular}{lcccccc}
\hline Population & \multicolumn{5}{c}{ Trait } \\
\cline { 2 - 7 } & $\begin{array}{c}\text { Days to 50\% } \\
\text { pollen-shed }\end{array}$ & $\begin{array}{c}\text { Days to 50\% } \\
\text { silking }\end{array}$ & $\begin{array}{c}\text { Days to 50\% } \\
\text { maturity }\end{array}$ & $\begin{array}{c}\text { Number of } \\
\text { leaves }\end{array}$ & $\begin{array}{c}\text { Plant height } \\
\text { (cm) }\end{array}$ & $\begin{array}{c}\text { Ear height } \\
\text { (cm) }\end{array}$ \\
\hline & & & & & & \\
PTMB1 & $58.7 \pm 0.7 \mathrm{a}$ & $62 \pm 1 \mathrm{a}$ & $92.5 \pm 1.5 \mathrm{a}$ & $21.7 \pm 0.4 \mathrm{a}$ & $221 \pm 6 \mathrm{ab}$ & $112 \pm 10 \mathrm{ab}$ \\
PTMB2 & $56.7 \pm 1.5 \mathrm{~b}$ & $60 \pm 2 \mathrm{ab}$ & $90 \pm 1 \mathrm{abc}$ & $21.7 \pm 0.7 \mathrm{a}$ & $240 \pm 6 \mathrm{a}$ & $137 \pm 10 \mathrm{a}$ \\
PTMB3 & $55.7 \pm 0.4 \mathrm{~b}$ & $58.7 \pm 0.7 \mathrm{~b}$ & $87.5 \pm 1.5 \mathrm{cde}$ & $21 \pm 0.5 \mathrm{ab}$ & $220 \pm 7 \mathrm{ab}$ & $127 \pm 10 \mathrm{ab}$ \\
PTMB4 & $48 \pm 0.5 \mathrm{~d}$ & $48.7 \pm 0.7 \mathrm{~d}$ & $80.5 \pm 0.7 \mathrm{~g}$ & $17.7 \pm 0.4 \mathrm{e}$ & $159 \pm 4 \mathrm{c}$ & $66 \pm 4 \mathrm{c}$ \\
PTMB5 & $56.7 \pm 1.1 \mathrm{~b}$ & $59.7 \pm 1.2 \mathrm{ab}$ & $88 \pm 2 \mathrm{bcd}$ & $20.5 \pm 0.5 \mathrm{~b}$ & $207 \pm 12 \mathrm{~b}$ & $109 \pm 18 \mathrm{~b}$ \\
PTMB6 & $53.5 \pm 0.7 \mathrm{c}$ & $55 \pm 1 \mathrm{c}$ & $85.5 \pm 0.7 \mathrm{def}$ & $19.2 \pm 0.7 \mathrm{~cd}$ & $210 \pm 11 \mathrm{~b}$ & $106 \pm 9 \mathrm{~b}$ \\
PTMB7 & $53.2 \pm 0.4 \mathrm{c}$ & $55 \pm 0 \mathrm{c}$ & $84.5 \pm 0.7 \mathrm{f}$ & $20 \pm 0.5 \mathrm{bc}$ & $207 \pm 12 \mathrm{~b}$ & $114 \pm 14 \mathrm{ab}$ \\
PTMB8 & $52.7 \pm 1.4 \mathrm{c}$ & $54.2 \pm 1.9 \mathrm{c}$ & $84.5 \pm 2.5 \mathrm{f}$ & $18.5 \pm 0.5 \mathrm{de}$ & $175 \pm 10 \mathrm{c}$ & $80 \pm 12 \mathrm{c}$ \\
PTMB9 & $57 \pm 1 \mathrm{ab}$ & $59 \pm 1.5 \mathrm{~b}$ & $90.5 \pm 0.7 \mathrm{ab}$ & $20.5 \pm 0.5 \mathrm{bc}$ & $220 \pm 7 \mathrm{ab}$ & $127 \pm 15 \mathrm{ab}$ \\
DMRESRW & $52.5 \pm 0.5 \mathrm{c}$ & $54.5 \pm 1 \mathrm{c}$ & $85 \pm 1 \mathrm{ef}$ & $18.7 \pm 0.7 \mathrm{de}$ & $161 \pm 17 \mathrm{c}$ & $79 \pm 11 \mathrm{c}$ \\
\hline \multicolumn{5}{c}{ For each trait, means followed by the same letter are not significantly different at the 5\% level. } & \\
\end{tabular}

\section{DISCUSSION}

The seeds of the traditional populations were collected from farmers who usually draw them from their harvests without respecting the principles of conservative selection. The traditional populations evaluated resulted then from diverse evolutions depending on factors able to modify allelic frequencies (sample size, uncontrolled hybridizations, mutations, selection and mixtures notably).

Relatively important earliness differences up to 13 days were observed among traditional populations. Nevertheless, populations ranking for days to flowering (pollen-shed or silking) and days to maturity showed some dissimilarities due to differences of maturation phase (flowering - maturity phase) duration. The maturation phase which includes grain filling phase is an important period of yield elaboration. In tropical zone, any lengthening of the grain filling phase may be directly beneficial for yield (Edmeades and Tollenaar, 1988; Feil et al., 1992). For plant and ear heights, populations ranking was similar. The high correlation between those two traits reported by Kim and Hallauer (1989) may explain that. A great variability of grain yield shown by high standard error was observed for some populations. Its cause may be the heterogeneity of the experimental environment and/or the populations. Further evaluation may permit to obtain more precise values.

The principal components analysis showed that grain yield was not correlated with cycle duration. Such a result is unusual in maize. Generally, grain yield is positively correlated with cycle duration. The result obtained is, nevertheless, in agreement with those reported by Abadassi (2013). That author compared two types of improved tropical maize populations during two years in two locations of Benin and found that the most yielding variety was not the latest population but the earliest. The genetic constitution of the populations may explain the discordance. 
Table 3: Population means and their standard errors for rust score, husk cover and grain yield and its components.

\begin{tabular}{|c|c|c|c|c|c|c|}
\hline \multirow[t]{2}{*}{ Population } & \multicolumn{6}{|c|}{ Trait } \\
\hline & Rust & Husk cover & $\begin{array}{c}\text { Number of ears } \\
\text { per plant }\end{array}$ & $\begin{array}{c}\text { Number of grains } \\
\text { per ear }\end{array}$ & $\begin{array}{c}1000 \text { grain weight (g) } \\
\text { (1) }\end{array}$ & $\begin{array}{c}\text { Grain yield (kg/ha) } \\
\text { (1) }\end{array}$ \\
\hline PTMB2 & $1.7 \pm 0.4 b$ & $1.2 \pm 0.4 b$ & $0.87 \pm 0.08 \mathrm{~cd}$ & $333 \pm 37 a$ & $219 \pm 2$ & $2900 \pm 519$ \\
\hline PTMB3 & $1.7 \pm 0.4 b$ & $1 \pm 0 b$ & $1.17 \pm 0.04 \mathrm{ab}$ & $326 \pm 26 a b$ & $233 \pm 24$ & $3667 \pm 278$ \\
\hline PTMB6 & $1.5 \pm 0.5 b$ & $1 \pm 0 b$ & $1.12 \pm 0.14 \mathrm{abc}$ & $270 \pm 32 \mathrm{bcd}$ & $244 \pm 11$ & $3088 \pm 537$ \\
\hline PTMB7 & $1.7 \pm 0.6 b$ & $1.2 \pm 0.5 b$ & $1.18 \pm 0.07 \mathrm{ab}$ & $256 \pm 19 c d$ & $245 \pm 17$ & $3200 \pm 475$ \\
\hline PTMB8 & $1.5 \pm 0.7 b$ & $3 \pm 0 \mathrm{a}$ & $0.91 \pm 0.08 \mathrm{~cd}$ & $334 \pm 39 a$ & $248 \pm 23$ & $3357 \pm 528$ \\
\hline PTMB9 & $1.2 \pm 0.4 \mathrm{~b}$ & $1.5 \pm 0.7 b$ & $1.05 \pm 0.07 \mathrm{abcd}$ & $336 \pm 14 a$ & $250 \pm 19$ & $3852 \pm 386$ \\
\hline DMRESRW & $1.5 \pm 0.5 b$ & $3 \pm 0 \mathrm{a}$ & $0.93 \pm 0.07 \mathrm{bcd}$ & $317 \pm 27 \mathrm{ab}$ & $240 \pm 29$ & $3108 \pm 473$ \\
\hline
\end{tabular}

For each trait, means followed by the same letter are not significant
(1) For that trait, population effect was not significant $(\mathrm{P}>0.05)$.

Table 4: Principal components analysis: eigenvalues.

\begin{tabular}{lcc}
\hline & AXIS 1 & AXIS 2 \\
\hline Eigenvalue & 2.794 & 0.949 \\
Proportion of total variability represented $(\%)$ & 69.847 & 23.734 \\
\hline
\end{tabular}


Table 5: Principal components analysis: squared cosines of the variables.

\begin{tabular}{lcc}
\hline & AXIS 1 & AXIS 2 \\
\hline Days to 50\% silking & 0.961 & 0.002 \\
Days to 50\% maturity & 0.924 & 0.003 \\
Plant height & 0.802 & 0.057 \\
Grain yield & 0.106 & 0.888 \\
\hline
\end{tabular}

Table 6: Principal components analysis: simple linear correlation matrix of the variables.

\begin{tabular}{lcccc}
\hline Variables & $\begin{array}{c}\text { Days to 50\% } \\
\text { silking }\end{array}$ & $\begin{array}{c}\text { Days to 50\% } \\
\text { maturity }\end{array}$ & $\begin{array}{c}\text { Plant } \\
\text { height }\end{array}$ & $\begin{array}{c}\text { Grain } \\
\text { yield }\end{array}$ \\
\hline Days to 50\% silking & 1 & $0.959^{* *}$ & $0.836^{* *}$ & $-0.269^{\mathrm{ns}}$ \\
Days to 50\% maturity & $0.959^{* *}$ & 1 & $0.786^{* *}$ & $-0.245^{\mathrm{ns}}$ \\
Plant height & $0.836^{* *}$ & $0.786^{* *}$ & 1 & $-0.096^{\mathrm{ns}}$ \\
Grain yield & $-0.269^{\mathrm{ns}}$ & $-0.245^{\mathrm{ns}}$ & $-0.096^{\mathrm{ns}}$ & 1 \\
\hline${ }^{* *}$ Highly significant (1\% level); ${ }^{\mathrm{ns}}$ non-significant. & & & \\
\hline
\end{tabular}

On the basis of the means, certain populations such as PTMB1 and PTMB2, PTMB3 and PTMB9, PTMB6 and PTMB7 appeared relatively close for most of the traits studied. They could have derived from the same original traditional population which could have evolved differently due to its growing in farmers' fields in different conditions and beside different populations with which natural mating could have occurred. They may also originate from different original populations which could have drawn nearer after natural mating favoured by growing in neighbouring fields. Another cause of original population evolution may be the empiric selection applied by farmers while drawing seeds from the harvests.

The absence of significant difference between the improved population DMRESRW and the traditional populations for grain yield was not expected. Introduced improved maize varieties generally have grain yield potentials higher than those of traditional populations (Kossou et al., 1993; Abadassi, 2001, 2013). The similarity observed may be due, partially, to gene flows between the improved population and the traditional populations cultivated sometimes side by side in farmers' fields in Benin. Further work involving several locations will permit to compare more precisely the traditional populations and DMRESRW for grain yield.

Molecular markers widely used to evaluate genetic relationships among populations (Sanou et al., 1997; Garcia et al., 2004; Beyene et al., 2005, 2006; Bige and Lorenzoni, 2007; Bernardo, 2008; Karanja et al., 2009; Morales et al., 2010; Arief et al., 2013) may permit to specify the genetic relationships among the populations studied.

\section{Conclusion}

Significant differences were noted among the traditional populations evaluated for earliness, plant and ear heights, number of ears per plant and number of grains per ear. One population (PTMB4) was susceptible to rust. All populations except one (PTMB8) had good husk cover. The traditional populations gave relatively low grain yields and no significant difference was observed among populations for that trait.

The 9 traditional populations are already preferred by Beninese producers and 
consumers to the introduced improved varieties particularly for the good quality of their grains and their relatively low susceptibility to storage pests and are widely cultivated. But, their grain yields may be improved without modification of the characteristics needed in them. The populations PTMB4 and PTMB8 should, in addition, be improved respectively for rust resistance and husk cover. Release of such improved populations, will contribute to increase maize production in Benin.

\section{REFERENCES}

Abadassi J. 1997. Contraintes de la production du maïs et du niébé au Bénin. Rapport de recherche. Faculté des Sciences Agronomiques, Université d'AbomeyCalavi, Abomey-Calavi, Bénin.

Abadassi J. 2001. Caractérisation de quelques variétés améliorées de maïs cultivées au Bénin. Bulletin de la Recherche Agronomique du Bénin, 34: 1-8.

Abadassi J. 2013. Comparison of two types of improved tropical maize populations in Benin. African Journal of Agricultural Research, 8: 952-956.

Adegbola P. 1994. Expériences et acquis pays dans la culture du maïs au sud du Bénin. Actes du séminaire «Maïs prospère », 25 - 28 Janvier 1994, Cotonou, Bénin.

Arief VN, Delacy IH, Wenzl P, Dreisigacker S, Crossa J, Dieters MJ, Basford KE. 2013. Using mplecular marker order to compare genetic structure in plant populations undergoing selection. Journal of Environmental Statistics, 4: 116.

Bernardo R. 2008. Molecular markers and selection for complex traits in plants: learning from the last 20 years. Crop Sci., 48: 1649-1664.

Beyene Y, Botha A-M, Myburg AA. 2005. Genetic diversity in traditional Ethiopian highland maize accessions assessed by AFLP markers and morphological traits. Biodiversity and Conservation, 15: 2655-2671.
Beyene Y, Botha A-M, Myburg AA. 2006. Genetic diversity among traditional Ethiopian highland maize accessions assessed by Simple Sequence Repeat (SSR) Markers. Genetic Resources and Crop Evolution, 53:1579-1588.

Bige T, Lorenzoni C. 2007. Characterization of maize (Zea mays L.) germplasm of Angola. Maydica, 52: 135-144.

Edmeades, GO, Tollenaar M. 1988. Genetic and cultural improvements in maize production. Proceedings of the International Congress of Plant Physiology Society for plant physiology and biochemistry, New Delhi, 165-180.

FAO. 2013. FAO Statistical Yearbook 2013. FAO: Rome, Italy.

Feil B, Thiraporn R, Geisler G, Stamp P. 1992. Yield, development and nutrient efficiency of temperate and tropical maize germplasm in the tropical lowlands. 2. Uptake and redistribution of nitrogen, phosphorus and potassium. Maydica, 37: 199-207.

Fiagan YS. 1994. Le système de stockage du maïs en milieu paysan béninois: bilan et perspectives. Actes du séminaire «Maïs prospère », 25-28 Janvier 1994, Cotonou, Bénin.

Garcia AAF, Benchimol LL, Barbosa AMM, Geraldi IO, Souza Jr. CL, de Souza AP. 2004. Comparison of RAPD, RFLP, AFLP and SSR markers for diversity studies in tropical maize lines. Genet. Mol. Biol., 27: 579-588.

Karanja J, Amugune NO, Ininda J, Kimatu JN, Danson JW. 2009. Microsatellite analysis of the correlation between molecular and morphological traits in assorted maize inbred lines. African Crop Science Journal, 17: 133-144.

Kim SK, Hallauer AR. 1989. Agronomic traits of tropical and subtropical maize inbreds in Iowa. Plant Varieties, 2: 85-91.

Kossou KD, Mareck JH, Bosquez-Pérez NA. 1993. Comparison of improved and local maize varieties in the Republic of Benin with emphasis on susceptibility to Sitophilus zeamais Motschulsky. Journal 
of Stored Products Research, 29: 333343.

Mir C, Zerjal T, Combes V, Dumas F, Madur D, Bedoya C, Dreisigacker S, Franco J, Grudloyma P, Hao PX, Hearne S, Jampatong C, Laloe D, Muthamia Z, Nguyen T, Prasanna BM, Taba S, Xie CX, Yunus M, Zhang S, Warburton ML, Charcosset A. 2013. Out of America: tracing the genetic footprints of the global diffusion of maize. Theoretical Applied Genetics, 126: 2671-2682.

Morales M, Decker V, Ornella L. 2010. Analysis of genetic diversity in Argentinian heterotic maize populations using molecular markers. Cien. Inv. Agr., 37: 151-160.

ONASA (Office National d'Appui à la Sécurité Alimentaire). 2013. Evaluation de la production vivrière en 2012 et perspectives alimentaires pour 2013 au Bénin. Rapport général. ONASA, Cotonou, Bénin.

Sanou J, Gouesnard B, Charrier A. 1997. Isozyme variability in West African maize cultivars (Zea mays L). Maydica, 42: 1-11.

Shiferaw B, Prasanna B, Hellin J, Banzigen M. 2011. Crops that feed the world 6 . Past successes and future challenges to the role played by maize in global food security. Food Security, 3: 307-327.

Westengen OT, Berg PR, Kent MP, Brysting AK. 2012. Spatial structure and climatic adaptation in African maize revealed by surveying SNP diversity in relation to global breeding and landrace panels. PloS one, 7: e47832. 